\title{
Influence of Heavy Weight Drill Pipe Material and Drill Bit Manufacturing Errors on Stress State of Steel Blades
}

\author{
Oleg Bazaluk ${ }^{1}\left(\right.$, Andrii Velychkovych ${ }^{2}\left({ }^{1}\right.$, Liubomyr Ropyak $^{3}$, Mykhailo Pashechko $^{4}$, Tetiana Pryhorovska ${ }^{5}$ \\ and Vasyl Lozynskyi ${ }^{6, *}$ \\ 1 Belt and Road Initiative Institute for Chinese-European Studies (BRIICES), \\ Guangdong University of Petrochemical Technology, Maoming 525000, China; bazaluk@ukr.net \\ 2 Department of Construction and Civil Engineering, Ivano-Frankivsk National Technical University of Oil and \\ Gas, 076019 Ivano-Frankivsk, Ukraine; a_velychkovych@ukr.net \\ 3 Department of Computerized Engineering, Ivano-Frankivsk National Technical University of Oil and Gas, \\ 076019 Ivano-Frankivsk, Ukraine; 1_ropjak@ukr.net \\ 4 Department of Fundamentals of Technology, Lublin University of Technology, 20618 Lublin, Poland; \\ m.pashechko@pollub.pl \\ 5 Department of Engineering and Computer Graphics, Ivano-Frankivsk National Technical University of Oil \\ and Gas, 076019 Ivano-Frankivsk, Ukraine; tetiana.pryhorovska@nung.edu.ua \\ 6 Department of Mining Engineering and Education, Dnipro University of Technology, 49005 Dnipro, Ukraine \\ * Correspondence: Lozynskyi.v.h@nmu.one
}

check for

updates

Citation: Bazaluk, O.; Velychkovych,

A.; Ropyak, L.; Pashechko, M.;

Pryhorovska, T.; Lozynskyi, V.

Influence of Heavy Weight Drill Pipe

Material and Drill Bit Manufacturing Errors on Stress State of Steel Blades.

Energies 2021, 14, 4198. https://

doi.org/10.3390/en14144198

Academic Editors: Sergey Zhironkin and Dawid Szurgacz

Received: 17 June 2021

Accepted: 10 July 2021

Published: 12 July 2021

Publisher's Note: MDPI stays neutral with regard to jurisdictional claims in published maps and institutional affiliations.

Copyright: (c) 2021 by the authors. Licensee MDPI, Basel, Switzerland. This article is an open access article distributed under the terms and conditions of the Creative Commons Attribution (CC BY) license (https:/ / creativecommons.org/licenses/by/ $4.0 /)$.

\begin{abstract}
Drilling volumes should be increased in order to increase hydrocarbon production, but this is impossible without the usage of high-quality drilling tools made of modern structural materials. The study has to analyze the design, technological and operational methods to increase the performance of drilling tools made of various materials and has highlighted prospects of technological method applications. The scientific novelty of the study consists in the development of a new analytical model of PDC drill bit-well interaction. The developed model takes into account the drill bit manufacturing errors in the form of bit body-nipple axes misalignment on the drill bit strength. This result makes it possible to determine the permissible manufacturing errors to provide safe operation of the drill bit. It is established that there is an additional transverse force that presses the drill bit to the well wall in the rock due to manufacturing errors. It is determined that the magnitude of this clamping force can be significant. The material effect has been analyzed on additional clamping force. It is established that geometric imperfection of the drill bit causes the minimal effect for the elastic system of the pipe string, which includes a calibrator and is composed of drill pipes based on composite carbon fiber material, and the maximal effect-for steel drill pipes. Polycrystalline diamond compact (PDC) drill bit and well wall contact interaction during operation in non-standard mode is considered. Non-standard stresses are determined, and the strength of the blades is estimated for different values of drilling bit manufacturing error.
\end{abstract}

Keywords: drilling; pipe; drill bit; manufacturing error; material; model; elastic modulus

\section{Introduction}

Nowadays, the global challenge is associated with the need to ensure sustainable development [1-4]. Despite the rapid development of green energy, oil and gas remain the main energy carriers [5,6]. In addition, coal processed by modern technologies is widely used as an energy source [7,8]. Demand for oil and gas will remain stable in the near future, and it means high oil and gas prices on the world market [9]. At the same time, the problem of providing energy to industries and the population is complicated by the fact that oil and gas deposits are deep and difficult to extract; this stipulates high requirements for materials and good quality drilling tools [10,11].

Drill bits operate under high loads, in corrosive and abrasive environments, and carbon-containing materials (steels and alloys) are the main type of material used to 
manufacture drilling equipment and tools. It should be noted that in addition to having an abrasive environment, rocks are heterogeneous with different physical and mechanical properties [12-15]. Crack coalescence is a significant phenomenon produced in rocks during the cutting process [16]; thus, it is necessary to provide a simulation of the crack's propagation and the effect of the in-situ stresses on the mechanical specific energy PDC cutter as shown in [17-19].

Modern smart composite materials, obtained by reinforcing the carbon matrix with fibrous carbon material (carbon-carbonic compositional materials), are used today to manufacture individual parts. These materials can potentially be used instead of drill pipes which are made out of traditional materials-aluminum alloys (duralumin), titanium alloys, and steel [20]. When drilling for oil, gas, and water and during the extraction of other minerals, rock is ruined and brought to the surface by the washing liquid because of the metal drill bit-rock interaction. The rigidity of the drill string, and hence the interaction between the drill bit and the rock, is dependent on the material of the drill pipe (the most commonly used are: steel of different strength groups, such as steel $40 \mathrm{KhN}$, aluminum alloys AD31 and duralumin D16T, titanium alloy VT1-0 as well as magnesium alloys and composite carbon materials) [21-23].

The smart drilling of wells is becoming more widespread [24,25], and increasing the depth of drilling and the construction of wells of various configurations requires new materials, structures, and advanced technologies for the manufacture of drilling tools to be used. Design, technological and operational methods are used to increase drilling tool performance [26,27]. Design methods include improving threaded joint tightness [28-30]; preventing self-unscrewing [31]; rational choice of materials by studying structural changes; conducting corrosion studies of metals [32-35], and studying the processes of destruction [36,37], including different types of coatings (if present) [38-41]; substantiation of the stress state of pipes [42]; optimization of armaments, supports and units for drill bit washing [43,44], etc. The works of [45-48] present new approaches to strength and optimization estimates according to the operational criteria of rotating bearing elements for mining machines.

Technological methods to improve drilling tool quality include a number of measures $[48,49]$. The most common are: increasing the accuracy of helical surfaces and surfaces of plain bearings [50-52], as well as laser processing of operational surfaces and grinding of threads [53,54]. Studies of metal structure [55-57] and diffusion processes [58-60] are necessary for the development of modern materials and hardening technologies. Coatings [60-63] occupy an important place among the methods of hardening and surfacing [64] and are used to provide high wear resistance of the operational surfaces of parts.

Various solid compounds and their mixtures are used as a coating material: oxides $[65,66]$, nitrides, and carbides [67,68] of the composition [69-71]. The use of electrochemical chromium plating on parts with low-toxic electrolytes is promising. Operational methods for improving drilling tool performance include drill string-bit oscillation mathematical modeling [72]; rational choice of drilling modes considering forces [73-76], temperature [77-79], life cycle control of threaded connections [80], and the rational choice of drill tube material for drill string assembling [81], as well as drill tube stress control [82].

The design features and specifics of drilling tools and their contact interaction with the well wall and face cause dynamic loads. Some authors [83-86] consider the vibration protection of drilling tools as a guarantee of ensuring high technical and economic performance of well drilling. Problems with designing vibration protection devices for long structures (drill columns, pump-compressor rods) were considered in [87-89]. The modeling of contact interaction in shell-rod systems under nonmonotonic loading to estimate the damping capacity of these systems was carried out in [90-93]. The issues on the mechanicalmathematical modeling of rod relation, referring to drill string problems [94-96], are still relevant. For the clarification of rod surface-an elastic or inelastic medium interaction model is required for the safe operation of pipelines [97-99], the increase reliability and durability of drill strings, and to ensure the quality centering of casings [100,101]. Digital technologies are used to account for the key indicators of mining operations [102]. 
The data presented in the literature review are not enough to assess the impact of drill bit manufacturing errors and drill string rigidity composed of pipes of different materials on bit-rock force interaction. Researchers pay considerable attention to the choice of materials and hardening technologies, but do not pay enough attention to substantiate the accuracy of PDC drill bits and study the bit-rock force interaction. The results of the analysis on drill bit manufacturing errors and drill string rigidity composed of pipes of different materials are necessary for the rational design of drill bits, the development of manufacturing technology, and substantiation of technological modes of drilling.

This work aims to study the influence of drill bit manufacturing errors and drill string rigidity composed of pipes of different materials on bit-rock force interaction and the prospects of latest carbon materials for drilling tool application compared with traditional materials (aluminum, titanium alloys and carbon steel).

To achieve this goal, the following tasks were set:

- to develop a mathematical model of drill bit rock interaction taking into account manufacturing errors.

- to investigate the influence of the mechanical properties of different classes of drill pipe materials on the additional force that clamps the drill bit to the well wall and the level of stresses in the metal bit.

\section{Materials and Methods}

We used the bibliosemantic method and content analysis to specify the main types of errors that occur during the manufacture of PDC drill bits for the first stage of this study. The analysis of previous scientific literature research, electronic resources, as well as practical and production experience of the authors, made it possible to identify the necessary scientific data and establish relationships between them and state an unsolved problem in this field. As a result, the purpose and objectives of the study were formulated.

We formulated the main ideas and concepts of the developed analytical model of bit blade-well bore interaction, which takes into account the drill bit body-nipple axes misalignment influence on the operational strength of the blades using the methods of structural-logical and system analysis.

In order to provide the practical implementation of the intended analytical model, we used methods from the mechanics of a deformable solid to obtain an analytical result for assessing the bit blade strength.

The analytical study was conducted in two stages. In the first stage, we studied the global change in the behavior of the elastic system "drill pipes-drill bit-well wall" depending on the magnitude of the bit manufacturing errors. In the second stage of the study, we studied the drill bit-rock interaction. As a result, an analytical expression was obtained to find the maximum equivalent stresses in the drill bit blade made with manufacturing errors.

The reliability of the obtained analytical results was confirmed by the validity of the geometric-linear formulation of the problem, the strict implementation of mathematical methods tested in the literature for analytical research, and the convergence of the results of individual partial cases with known results.

In order to provide the numerical analysis of our research results, we selected the following structural materials of drill pipes: carbon steel, aluminum alloys, titanium alloy, and composite carbon fiber material. Fine-crystalline limestone was used as a rock-forming material for the well wall. It was assumed that that the elastic properties of the considered materials are determined by their Young's moduli and Poisson's ratios, and that strength is regulated by the yield strength.

The physical and mechanical properties of the materials, the geometric dimensions of the drill bit, and drill pipes are given below when considering numerical examples. 


\section{Results}

There are a number of PDC drill bit manufacturing errors. In particular, as a result of the assembly operations of the welding blades with the body, screwing, and subsequent welding of the nipple with the bit body, there may be a radial runout of the blades and misalignment of the nipple-bit body which would worsen the operation conditions of the rock, destroying elements of the bit.

Let us determine the influence of the errors mentioned above on magnitude of the cutting force, the level of stresses, and the strength of the bit blades during rock drilling (Figure 1). Let the drill bit, which has a manufacturing error (nipple-body misalignment) of $\Delta$ (Figure $1 \mathrm{~b}$ ), operate in combination with a calibrator. The bit and the calibrator are connected by drill pipes made of different materials with a length of $l$.

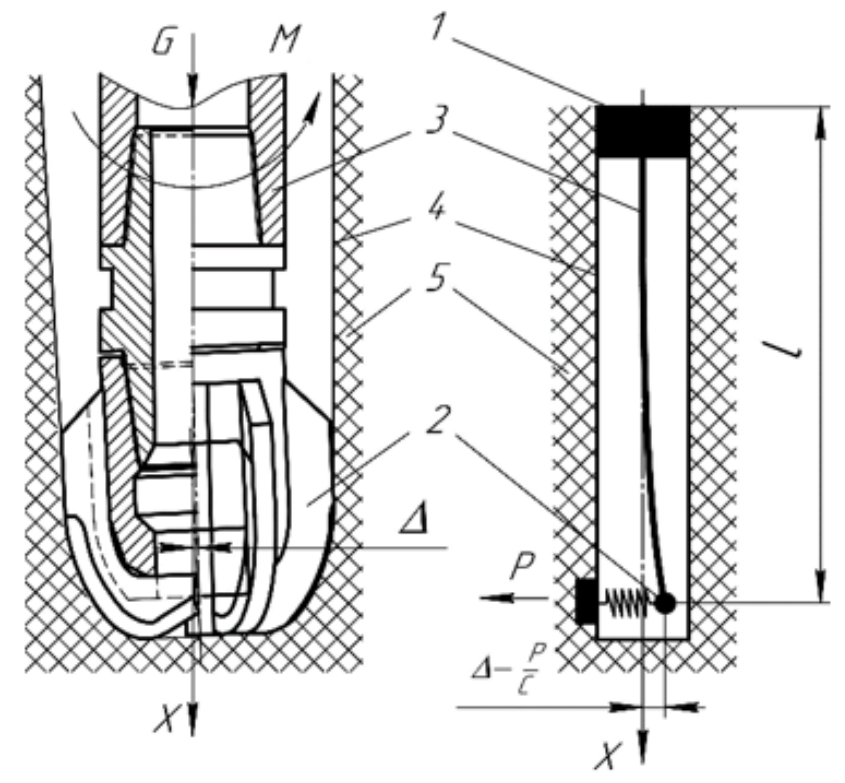

(a)

(b)

Figure 1. Interaction of the drill bit with the bottom hole of the well (a) and the calculation scheme for finding the force clamping the drill bit to the well wall (b): 1-calibrator; 2-PDC drill bit; 3-weighted drill pipe; 4-well wall; 5-rock.

To simplify the model, we assume that there is a clamp in position of the calibrator in the well. The manufacturing error will lead to a freelance kinematic load of the elastic system, as a result of which an additional transverse clamping force will appear on the bit (Figure 1a). The pliability, C, of the rock (see Equation (1)) to be contacted by the PDC bit is simulated by an elastic support with rigidity, so in comparison to it we will consider the bit absolutely rigid.

Using the principle of independence of forces for linear systems, we present the canonical equation for the method of forces:

$$
\delta_{11} P+\Delta_{1 p}=\Delta-\frac{1}{C} P,
$$

where $\delta_{11}=l^{3} / 3 E J$ and $\Delta_{1 p}=0$-transverse movements from the right end of the elastic system (released from the ligaments) caused by a unit force and an external force load, respectively; $E$ is the modulus of elasticity of the drill pipe material; $J=0.05 D^{4}\left[1-(d / D)^{4}\right]$ is the axial moment of inertia of the drill pipe cross-section; $d, D$ are the inner and outer diameters of the drill pipes. 
Solving Equation (1), we obtain the expression for the additional clamping force on the bit:

$$
P=\frac{\Delta}{\frac{1}{3} \frac{l^{3}}{E J}+\frac{1}{C}},
$$

Let us estimate a possible range for the clamping force $P$ depending on the nipplebody misalignment $\Delta$. To make the estimation more concrete, we need to choose a specific size for the weighted drill pipe with an outer diameter of $203 \mathrm{~mm}$ and an inner diameter of $80 \mathrm{~mm}$ and assume that the bit is in contact with an absolutely rigid rock (we obtain the upper range of possible clamping force). The distance between the bit and the first calibrator is $1 \mathrm{~m}$. We consider that the drill pipes are made of different metal alloys: steel alloy $40 \mathrm{KhN}$, aluminum alloy AD31, duralumin alloy D16, and titanium alloy VT1-0 with the following modules of elasticity: steel alloy-2.1 $\times 10^{5} \mathrm{MPa}$, aluminum alloy$6.7 \times 10^{4} \mathrm{MPa}$, duralumin alloy-7.3 $\times 10^{4} \mathrm{MPa}$, and titanium alloy- $1.12 \times 10^{5} \mathrm{MPa}$. It should be noted that today, modern technologies used for the manufacture of structural materials allow the use of smart composite materials for the production of drilling tools obtained by reinforcing the carbon matrix with carbon fiber material (carbon-carbonic compositional materials). In particular, drill pipes made of such materials demonstrate high economic efficiency in the oil and gas sector [102-106]. Therefore, for analysis, we chose another option - drill pipe based on composite carbon fiber material (modulus of elasticity in the axial direction of such material-5.6 $\times 10^{4} \mathrm{MPa}$ ).

Analysis of the dependences presented in Figure 2 shows that the geometric imperfection of the drill bit causes minimal effect on the elastic system of the pipe string, which includes a calibrator and is composed of drill pipes based on composite carbon fiber material, and the maximal effect-for steel drill pipes.

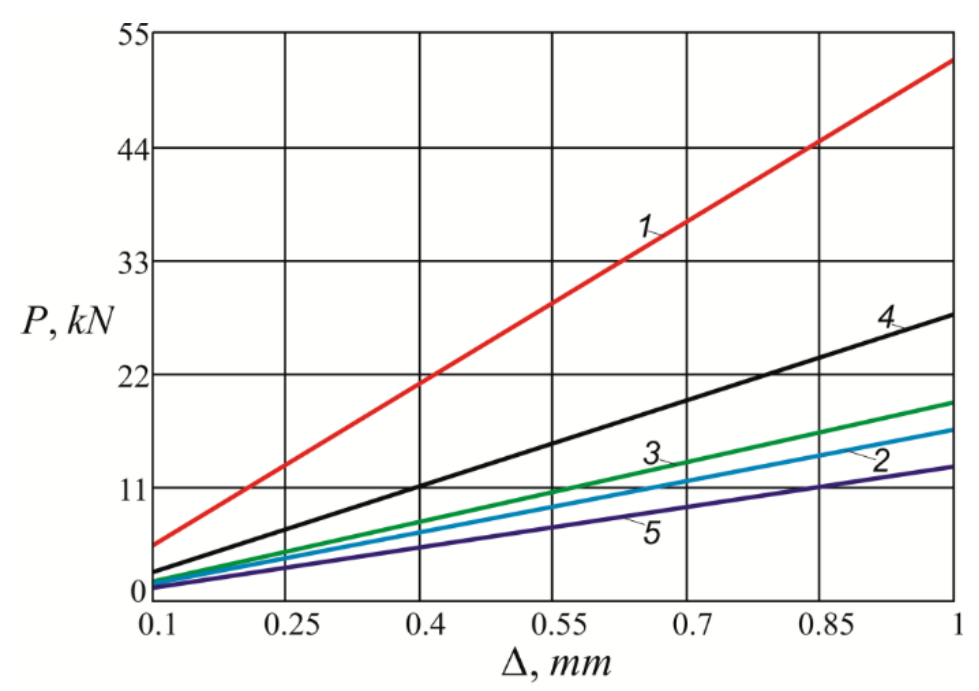

Figure 2. Abnormal transverse clamping force on the bit (upper range): 1-carbon steel; 2aluminum alloy; 3-duralumin alloy; 4-titanium alloy; 5-composite carbon fiber material.

In the case of pipes made of light alloys of aluminum and titanium, the magnitude of the clamping force is intermediate. Now we will consider in more detail the features of the drill bit (blade)-rock interaction.

The normal mode of operation requires the bit to be perfectly made (i.e., has no nipplebody misalignment, $\Delta=0$ ) and the well hole to be ideal, in that case each blade deeps into the rock for the same value of radial recess $a_{0}$ (Figure 3). 


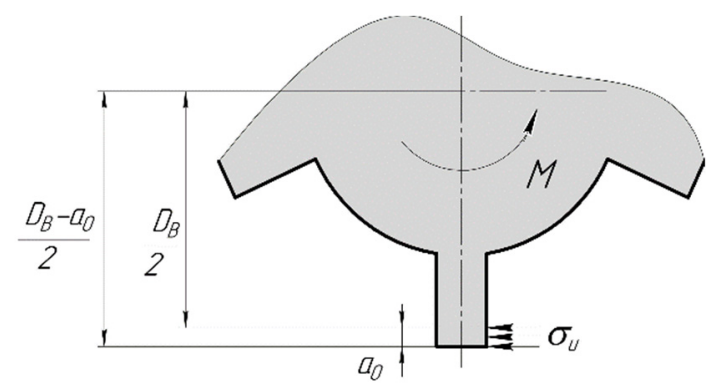

Figure 3. Scheme of blade-well wall contact interaction (normal mode of operation).

So long as $a_{0}$ is a small value, we assume that the contact stresses are evenly distributed over the blade-rock contact area. The cutting forces are distributed equally between all the blades of the bit. This way, the global equilibrium equation of the system, which refers to the longitudinal axis $O x$, can be represented as follows (for a six-blade bit $n=6$ ):

$$
M=\sum_{i=1}^{n} \sigma_{u} a_{0} H \frac{D_{b}-a_{0}}{2}=3 \sigma_{u} A_{0}\left(D_{b}-a_{0}\right),
$$

where $\sigma_{u}$ is the rock strength, $H$ is the blade length, $D_{b}$ is the diameter of the bit, $A_{0}$ is the blade-rock contact area, $M$ is the torque on the bit.

An abnormal mode of operation is when the bit is made with errors (i.e., has nipplebody misalignment $\Delta \neq 0$ ), and there is an inhomogeneous distribution of cutting forces between the blades of the bit. If $\Delta>a_{0}$, some blades lose contact with the rock, and heterogeneity of force distribution becomes significant and can cause a loss of drill bit strength. Figure 4 shows the two most unfavorable cases of blade-rock interaction.

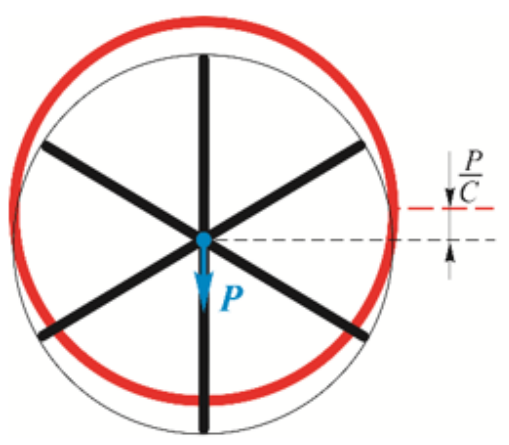

(a)

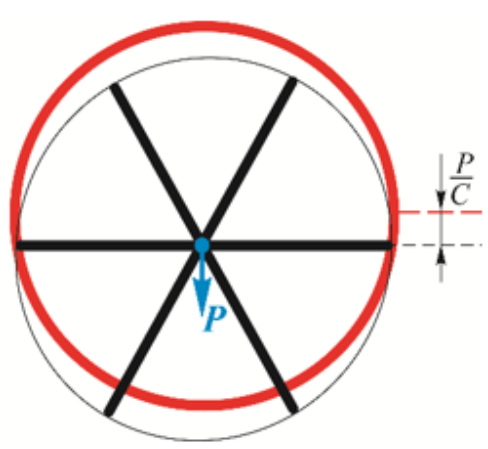

(b)

Figure 4. Contact interaction of the metal blades of the drill bit with the well wall (abnormal mode of operation): (a)—three blades operate; (b)—two blades operate.

Let us determine the additional radial recess $\Delta_{r}^{i}$ of the blade-rock interaction and radial forces $P_{i}$ associated with the abnormal case.

Assuming that the clamping force $P$ enforces the drill bit to move for $P / C=\delta$ directionally to this force action (Figure 5). Assuming the drill bit as a solid body, we neglect its deformations:

$$
b_{0} k_{0}=b_{1} k_{1}=b_{2} k_{2}=\frac{P}{C}=\delta .
$$

for an arbitrarily located blade, one can always consider a triangle similar to the triangle $b_{2} s k_{2}$ (Figure 4) and express the radial displacements of the blades $\Delta_{r}^{i}$ using $\delta$. In this case:

$$
\Delta_{r}^{0}=\delta ; \Delta_{r}^{1}=\Delta_{r}^{2}=\delta \cos \vartheta
$$


radial $P_{i}$ and tangential $P_{t i}$ forces in the respective directions are found assuming that the reaction of the rock is proportional to the magnitude of the displacement. For the case shown in (Figure 5) we will have:

$$
P_{0}=\frac{1}{3} P ; P_{1}=P_{2}=\frac{1}{3} P \cos \vartheta, P_{t 0}=0, P_{t 1}=P_{t 2}=\frac{1}{3} P \sin \vartheta
$$

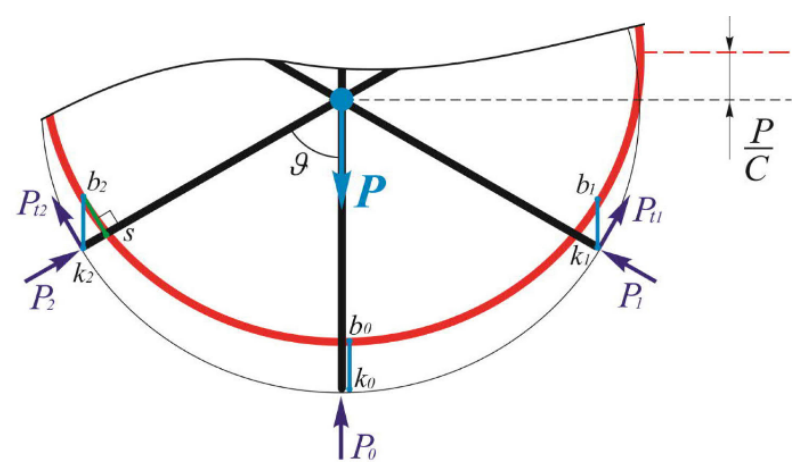

Figure 5. Calculation scheme for determining the additional radial recess of the rock $\Delta_{r}^{i}$ and the radial forces $P_{i}$.

This way, the global equilibrium equation of the system, written relative to the longitudinal axis of the bit, will take the following form (Figure 6):

$$
M=\sum_{i=1}^{n *}\left[\sigma_{u}\left(a_{0}+\Delta_{r}^{i}\right) H \frac{D_{b}-\left(a_{0}+\Delta_{r}^{i}\right)}{2}+f P_{i} \frac{D_{b}}{2}\right],
$$

where $n^{*}$-number of blades contacting with the rock; $f$-the blade-rock friction coefficient.

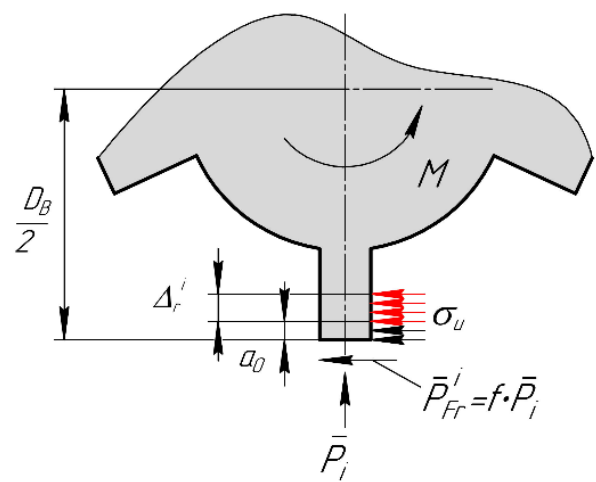

Figure 6. Scheme of the drill bit blade loading for abnormal mode of operation (black shows the standard loads, and red-additional, which arise due to an abnormal operation).

When performing numerical calculations, the stiffness of the model elastic support (see Figure 2) will be determined using the known values of the coefficient of subgrade resistance $k$. For this case:

$$
C=k n \cdot h H,
$$

where $h$ is the width of the blade.

Let us determine the maximum stresses that can occur in the material of the blade. We neglect the shear stresses due to the predominant influence of bending strength and axial load. Then for the normal case (Figure 7a):

$$
\left\{\begin{array}{l}
\sigma_{\max }^{+} \\
\sigma_{\max }^{-}
\end{array}= \pm \frac{M_{z}}{W_{z}}= \pm \frac{\left(\sigma_{u} a_{0} H\right)\left(L-\frac{a_{0}}{2}\right)}{\frac{H h^{2}}{6}}= \pm \frac{6}{h^{2}} \sigma_{u} a_{0}\left(L-\frac{a_{0}}{2}\right),\right.
$$


where $\sigma_{\max }^{+}$and $\sigma_{\max }^{-}$are the max tensile and compressive stresses of the blade; $M_{z}$ is the max bending moment; $W_{z}$ is the axial moment of resistance; and $L$ and $h$ are the height and width of the blade. $\mathrm{F}-\sigma \Delta \cdot$.

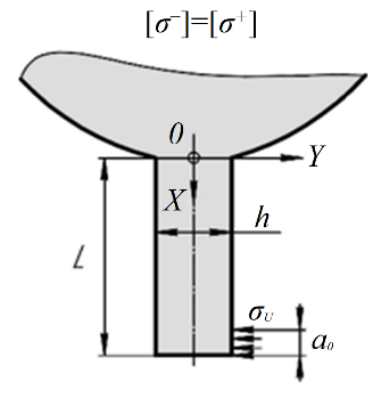

(a)

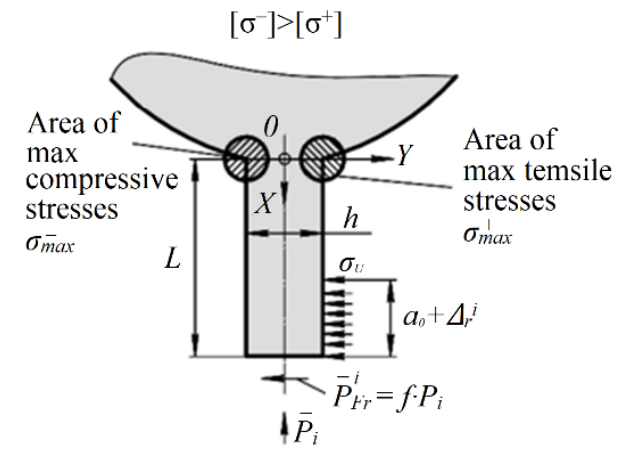

(b)

Figure 7. Calculation scheme for assessing the strength of the blade: (a) is normal mode of operation, (b) is abnormal mode of operation.

The vertical blade was the most loaded one for the abnormal mode of operation (Figure 4a). Figure $7 \mathrm{~b}$ presents the calculation scheme for PDC drill bit operation in the non-standard mode. The max tensile and compressive stresses in the blade material are:

$$
\left\{\begin{array}{l}
\sigma_{\max }^{+} \\
\sigma_{\max }^{-}
\end{array}=-\frac{N_{x}}{A_{b l}} \pm \frac{M_{z}}{W_{z}}=-\frac{P_{i}}{H h} \pm \frac{\left(\sigma_{u}\left(a_{0}+\Delta_{r}^{i}\right) H\right)\left(L-\frac{a_{0}+\Delta_{r}^{i}}{2}\right)+f P_{i} L}{\frac{H h^{2}}{6}}\right.
$$

where $A_{b l}$ is the cross-sectional area of the blade; $N_{x}$ the axial force.

The max stresses (modulus):

$$
\left|\sigma_{\max }^{-}\right|=\frac{1}{A_{b l}}\left[P_{i}+\frac{6}{h}\left(\left(\sigma_{u}\left(a_{0}+\Delta_{r}^{i}\right) H\right)\left(L-\frac{a_{0}+\Delta_{r}^{i}}{2}\right)+f P_{i} L\right)\right] .
$$

If the blade is made of plastic material, it is necessary for strength ensuring to provide the stresses calculated by Formula (8) less than the allowable stresses.

If the blade is placed at an angle in the direction of the clamping force (see Figure 5), it is necessary to take into account the effect on the magnitude of the tangential force $P_{t i}$ :

$$
\left\{\begin{array}{l}
\sigma_{\max }^{+} \\
\sigma_{\max }^{-}
\end{array}=-\frac{P_{i}}{H h} \pm 6 \frac{\left(\sigma_{u}\left(a_{0}+\Delta_{r}^{i}\right) H\right)\left(L-\frac{a_{0}+\Delta_{r}^{i}}{2}\right)+\left(f P_{i} \pm P_{t i}\right) L}{H h^{2}} .\right.
$$

Let us consider a specific numerical example. Consider a specific numerical example. Let the distance between the bit and the first calibrator be $l=1 \mathrm{~m}$. The inner and outer diameters of the weighted drill pipes are $d=147 \mathrm{~mm}$ and $D=190.5 \mathrm{~mm}$, the modulus of elasticity of the pipe material is $E=2.1 \times 10^{11} \mathrm{~Pa}$. Drilling is carried out with a six-bladed bit with the following parameters: $D_{b}=292 \mathrm{~mm}$ is the diameter of the bit; $H=226 \mathrm{~mm}$ is the blade length; $h=29.8 \mathrm{~mm}$ is the blade width; $L=49 \mathrm{~mm}$ is the blade height. The main rock that forms the well wall is fine-crystalline limestone with subgrade resistance $k=490 \mathrm{MN} / \mathrm{m}^{3}$ and tensile strength $\sigma_{u}=90 \mathrm{MPa}$. The rock-blade friction coefficient is $f=0.12$.

The axial moment of inertia of the cross-section of the weighted drill pipes is:

$$
J=0.05 D^{4}\left[1-\left(\frac{d}{D}\right)^{4}\right]=0.05 \cdot 190.5^{4}\left[1-\left(\frac{147}{190.5}\right)^{4}\right]=4.25 \times 10^{-5} \mathrm{~m}^{4}
$$


According to (5), the stiffness of the model elastic support for the case in (Figure 4a) is:

$$
C=k n \times h H=490 \cdot 10^{6} \cdot 3 \cdot 29.8 \cdot 10^{-3} \cdot 226 \cdot 10^{-3}=9.89 \cdot 10^{6} \mathrm{~N} / \mathrm{m} .
$$

assuming that the nipple-body misalignment $\Delta$ ranges from $0.2 \mathrm{~mm}$ to $1 \mathrm{~mm}$, by Equation (2), we determine the possible range of the additional transverse clamping force. For example, for $\Delta=0.4 \mathrm{~mm}$.

$$
P=\frac{\Delta}{\frac{1}{3} \frac{l^{3}}{E J}+\frac{1}{C}}=\frac{0.4 \cdot 10^{-3}}{\frac{1}{3} \cdot \frac{1^{3}}{2.1 \cdot 10^{11} \cdot 4.25 \cdot 10^{-5}}+\frac{1}{9.89 \cdot 10^{6}}}=2.89 \times 10^{3} \mathrm{~N}
$$

next, using the scheme presented in Figure 5, we calculate the additional radial recess of the blade in the rock:

$$
\Delta_{r}=\frac{P}{C} \cos \vartheta=\frac{2.89 \cdot 10^{3}}{9.89 \cdot 10^{6}} \cos 0=0.292 \mathrm{~mm} .
$$

and the radial force $P_{0}=P / 3=0.96 \mathrm{kN}$ caused by misalignment (if the blade is at an angle to the direction of the clamping force, it is also necessary to calculate the tangential force $\left.P_{t i}\right)$.

Next, we set the external torque (rotary drilling) $M=3 \mathrm{kN} \times m$, and from Equation (3), we determined the radial recess of the bit blades in the rock of the well wall during the ideal drilling process. Equation (8) calculated the maximum stresses that occur in the blades for the abnormal case (Table 1).

Table 1. Maximum stresses at different values of the bit manufacturing error.

\begin{tabular}{cccccc}
\hline Parameters & \multicolumn{5}{c}{ Misalignment $\Delta, \mathbf{~ m m}$} \\
\cline { 2 - 6 } & $\mathbf{0 . 2}$ & $\mathbf{0 . 4}$ & $\mathbf{0 . 6}$ & $\mathbf{0 . 8}$ & $\mathbf{1 . 0}$ \\
\hline Additional transverse clamping force $P, \mathrm{kN}$ & 1.45 & 2.89 & 4.33 & 5.78 & 7.22 \\
Additional radial recess $\Delta r, \mathrm{~mm}$ & 0.146 & 0.292 & 0.438 & 0.584 & 0.730 \\
Radial force caused by misalignment, $P_{0}, \mathrm{kN}$ & 0.48 & 0.96 & 1.44 & 1.92 & 2.41 \\
Radial force caused by the misalignment & 202.2 & 233.5 & 264.8 & 296.2 & 327.3 \\
$\left|\sigma_{\max }^{-}\right|$ & & & & & \\
\hline
\end{tabular}

Note: the maximum stresses in the blades of the perfectly made bit are $167.5 \mathrm{MPa}$ for the selected operating mode $M=3 \mathrm{kNm}$.

Analysis of the calculations given in Table 1 shows that drill bit manufacturing error increasing causes an increase in clamping force, additional radial recess, additional radial force, and maximum stresses in the blade. The growth of these indicators is significant, so it is necessary to provide technological methods to increase the accuracy of PDC drill bit manufacturing.

\section{Discussion}

The high standards of well construction envisage improved performance of modern drilling tools. Now, PDC drill bits are widely used, and their popularity in the world continues to grow. The main advantage of these drill bits over competitors is the lack of moving elements in the structure; in addition, they are technological in terms of manufacture and efficient in operation. To get all the possible benefits of PDC drill bits in practice, one needs to ensure the proper accuracy of the manufacture. Analysis of several series of PDC bits revealed that the main manufacturing errors are the magnitude of body-nipple misalignment.

The technology of PDC drill bit manufacturing envisages drill bit body and nipple assembling and further their welding as the final stage. Actually, the aforementioned manufacturing error occurs at this stage due to temperature deformations caused by welding. Such errors within an operation can affect the controllability of the bit. When using the bit with errors, additional stresses occur in drill string bottom hole assembling. 
Moreover, additional stresses occur in the elements of the bit. First, when the axes of the nipple and the body on the bit do not match, there is an additional transverse clamping force. It is determined that the aforementioned clamping force depends on the error magnitude, bottom hole assembly, pipe materials, and subgrade resistance of the rock.

If the PDC drill bit is manufactured with errors, cutting forces are distributed inhomogeneously between the blades of the bit. In some cases, some blades may lose contact with the rock, and in this case, the heterogeneity of force distribution becomes very significant and can cause a loss of structural strength. In particular, the provided numerical analysis showed that a drill bit body-nipple misalignment error is associated with an additional clamping force which can exceed $7 \mathrm{kN}$ (for using steel pipes of wide range). This clamping force can significantly affect the bit-wellbore contact interaction due to the additional radial recess of the blades in the rock. The maximum equivalent stress in the bit blades can be more than the standard one by almost two times.

When performing numerical testing of the results, we considered the bottom hole assemblies made of different metal alloys (steel alloy, aluminum alloy, duralumin alloy, titanium alloy) and also considered drill Pipe Based on Composite Carbon Fiber Material.

Among a number of currently known materials used for weighted drill pipes, composite carbon drill pipes [102] have shown minimal sensitivity to the geometric imperfection of the bit. Researchers [103-107] study the mechanical properties of polymers and the stress state, but there is no data on the operation of the drill string of pipes made of composite carbon materials and the bit. Analysis of the bit-well contact interaction during operation in non-standard mode allowed assessing the non-standard stresses that occur in the blades of the bit. Such results allow estimating the durability of blades and defining admissible errors of manufacturing at which operation of the bit will remain safe.

\section{Conclusions}

Analysis of previous studies has identified the main types of errors associated with PDC drill bit technology. In particular, body-nipple screwing, and subsequent welding can cause a body-nipple misalignment error-a mismatch between the axes of the nipple and the body.

We have developed an analytical model of the bit blade-rock contact interaction that takes into account the aforementioned nipple-body axes mismatch influence on the maximum equivalent stresses in the material of the blades. We considered that the error in the manufacture of the bit leads to a free kinematic load of the elastic system "drill pipes-bit-wellbore", resulting in an additional transverse clamping force acting on the bit. We simulated the behavior of the rock in contact with the bit as elastic support, the rigidity of which is expressed through the coefficient of subgrade resistance. After that, we considered the features of the rock-drill bit contact interaction for the standard and non-standard modes. It was found that the transverse clamping force on the bit causes additional radial recess of the blades into the rock if the blade operates in the non-standard mode. As a result, there is a significantly heterogeneous distribution of cutting forces between the blades of the bit, which in certain circumstances can lead to a loss of structural strength and an emergency during the construction of the well. As a result, we have obtained an analytical relation to specify the maximum equivalent stresses in the bit blade material for drill bits made with errors.

We specified the PDC drill bit nipple-body misalignment effect on the load on the steel blades for concrete numerical samples. Simulations have shown that the nipple-body misalignment increasing causes an increase in the clamping force. It is determined that the magnitude of the clamping force can become significant.

Peculiarities of drill bit-well wall contact interaction during operation in non-standard mode are considered. Extraordinary stresses were determined, and the strength of the blades with bit manufacturing errors was estimated.

The influence of the mechanical properties of different materials of weighted drill pipes on the value of free-force clamping force is analyzed. It is established that the least 
sensitivity to the geometric imperfection of the drill bit is shown by the elastic system of the pipe string, which includes a calibrator and is composed of composite carbon drill pipes. (Drill Pipe Based on Composite Carbon Fiber Material), and the largest-from steel drill pipes.

Further research is planned to take into account the stiffness of the threaded joints when calculating the transverse force that clamps the metal drill bit to the well wall.

Author Contributions: Conceptualization, A.V. and O.B.; methodology, A.V.; software, T.P.; validation, L.R., A.V. and M.P.; formal analysis, A.V.; investigation, V.L.; resources, M.P.; data curation, A.V.; writing—original draft preparation, V.L.; writing—review and editing, A.V.; visualization, T.P.; supervision, L.R.; project administration, O.B. and L.R.; funding acquisition, O.B. All authors have read and agreed to the published version of the manuscript.

Funding: This study was carried out as part of the project "Belt and Road Initiative Institute for Chinese-European studies (BRIICES)" and was funded by the Guangdong University of Petrochemical Technology.

Institutional Review Board Statement: Not applicable.

Informed Consent Statement: Not applicable.

Data Availability Statement: Data are contained within the article.

Acknowledgments: The team of authors express their gratitude to the reviewers for valuable recommendations that have been taken into account to improve significantly the quality of this paper. The authors are grateful to the Ministry of Science and Education of Ukraine for the grant to implement the project D-8-21-P.

Conflicts of Interest: The authors declare no conflict of interest.

\section{References}

1. Zhironkin, S.; Demchenko, S.; Kayachev, G.; Taran, E.; Zhironkina, O. Convergent and nature-like technologies as the basis for sustainable development in the 21st Century. E3S Web Conf. 2019, 105, 03008. [CrossRef]

2. Ursul, A.; Ursul, T.; Dugarova, M. Towards a global sustainable future. Philos. Cosmol. 2017, 15, 37-50.

3. Zhironkin, S.; Khloptsov, D.; Skrylnikova, N.; Petinenko, I.; Zhironkina, O. Economic principles of mining region sustainable development. E3S Web Conf. 2018, 41, 04010. [CrossRef]

4. Rozin, V. From engineering and technological process to post-cultural technology. Future Hum. Image 2020, 15, 99-109. [CrossRef]

5. IEA. World Energy Outlook. Flagship Report-2019; International Energy Agency: Paris, France, 2019. Available online: https: //www.iea.org/reports/world-energy-outlook-2019 (accessed on 20 May 2021).

6. Krichevskiy, S. Evolution of technologies, "green" development and grounds of the general theory of technologies. Philos. Cosmol. 2015, 14, 120-139.

7. Falshtynskyi, V.; Saik, P.; Lozynskyi, V.; Dychkovskyi, R.; Petlovanyi, M. Innovative aspects of underground coal gasification technology in mine conditions. Min. Miner. Depos. 2018, 12, 68-75. [CrossRef]

8. Lozynskyi, V.; Medianyk, V.; Saik, P.; Rysbekov, K.; Demydov, M. Multivariance solutions for designing new levels of coal mines. Rud. Geol. Naft. Zb. 2020, 35, 23-31. [CrossRef]

9. Le Billon, P.; Kristoffersen, B. Just cuts for fossil fuels? Supply-side carbon constraints and energy transition. Environ. Plan. A Econ. Space 2020, 52, 1072-1092. [CrossRef]

10. Bazaluk, O.; Slabyi, O.; Vekeryk, V.; Velychkovych, A.; Ropyak, L.; Lozynskyi, V. A technology of hydrocarbon fluid production intensification by productive stratum drainage zone reaming. Energies 2021, 14, 3514. [CrossRef]

11. Svyrydenko, D.; Mozgin, W. The soft power of the state as a dialectic of contemporary dependencies in the international arena. Ukrainian Policymaker 2019, 5, 89-97. [CrossRef]

12. Olovyannyy, A.; Chantsev, V. Numerical experiments concerning long-term deformation of rock samples. Min. Miner. Depos. 2019, 13, 18-27. [CrossRef]

13. Babets, D.V.; Sdvyzhkova, O.O.; Larionov, M.H.; Tereshchuk, R.M. Estimation of rock mass stability based on probability approach and rating systems. Nauk. Visnyk Natsionalnoho Hirnychoho Universytetu 2017, 2, 58-64.

14. Gorova, A.; Pavlychenko, A.; Borysovs'ka, O. The study of ecological state of waste disposal areas of energy and mining companies. In Annual Scientific-Technical Colletion-Mining of Mineral Deposits; CRC Press: Boca Raton, FL, USA, 2013 ; pp. 169-172. [CrossRef]

15. Khomenko, O.; Barna, T. Zonal-and-wave structure of open systems on micro, mega- and macrolevels of the universe. Philos. Cosmol. 2019, 22, 24-32. [CrossRef] [PubMed] 
16. Haeri, H.; Marji, M.F. Simulating the crack propagation and cracks coalescence underneath TBM disc cutters. Arab. J. Geosci. 2016, 9, 124. [CrossRef]

17. Marji, M.F. Modeling of Cracks in Rock Fragmentation with a Higher Order Displacement Discontinuity Method. Ph.D. Thesis, Middle East Technical University, Ankara, Turkey, 1996.

18. Marji, M.F. Simulation of crack coalescence mechanism underneath single and double disc cutters by higher order displacement discontinuity method. J. Cent. South Univ. 2015, 22, 1045-1054. [CrossRef]

19. Behnia, M.; Goshtasbi, K.; Marji, M.F.; Golshani, A. Numerical simulation of crack propagation in layered formations. Arab. J. Geosci. 2013, 7, 2729-2737. [CrossRef]

20. Bondarenko, V.; Kovalevs'ka, I.; Ganushevych, K. Progressive Technologies of Coal, Coalbed Methane, and Ores Mining; CRC Press: London, UK, 2014; 523p. [CrossRef]

21. Dreus, A.Y.; Sudakov, A.K.; Kozhevnikov, A.A.; Vakhalin, Y.N. Study on thermal strength reduction of rock formation in the diamond core drilling process using pulse flushing mode. Nauk. Visnyk Natsionalnoho Hirnychoho Universytetu 2016, 3, 5-10.

22. Sobko, B.; Lozhnikov, O.; Levytskyi, V.; Skyba, G. Conceptual development of the transition from drill and blast excavation to non-blasting methods for the preparation of mined rock in surface mining. Rud. Geol. Naft. Zb. 2019, 34, 21-28. [CrossRef]

23. Moisyshyn, V.; Voyevidko, I.; Tokaruk, V. Design of bottom hole assemblies with two rock cutting tools for drilling wells of large diameter. Min. Miner. Depos. 2020, 14, 128-133. [CrossRef]

24. Araujo, A.C.; Landon, Y.; Lagarrigue, P. Smart drilling for Aerospace Industry: State of art in research and education. Procedia CIRP 2021, 99, 387-391. [CrossRef]

25. Dychkovskyi, R.O.; Lozynskyi, V.H.; Saik, P.B.; Petlovanyi, M.V.; Malanchuk, Y.Z.; Malanchuk, Z.R. Modeling of the disjunctive geological fault influence on the exploitation wells stability during underground coal gasification. Arch. Civ. Mech. Eng. 2018, 18, 1183-1197. [CrossRef]

26. Falshtynskyi, V.S.; Dychkovskyi, R.O.; Lozynskyi, V.G.; Saik, P.B. Determination of the technological parameters of borehole underground coal gasification for thin coal seams. J. Sustain. Min. 2013, 12, 8-16. [CrossRef]

27. Bazaluk, O.; Sai, K.; Lozynskyi, V.; Petlovanyi, M.; Saik, P. Research into dissociation zones of gas hydrate deposits with a heterogeneous structure in the Black Sea. Energies 2021, 14, 1345. [CrossRef]

28. Onysko, O.R.; Kopey, V.B.; Panchuk, V.G. Theoretical investigation of the tapered thread joint surface contact pressure in the dependence on the profile and the geometric parameters of the threading turning tool. IOP Conf. Ser. Mater. Sci. Eng. 2020, 749, 012007. [CrossRef]

29. Onysko, O.; Borushchak, L.; Kopei, V.; Lukan, T.; Medvid, I.; Vryukalo, V. Computer studies of the tightness of the drill string connector depending on the profile of its tapered thread. Lect. Notes Netw. Syst. 2020, 128, 720-729. [CrossRef]

30. Onysko, O.; Kopei, V.; Medvid, I.; Pituley, L.; Lukan, T. Influence of the Thread Profile Accuracy on Contact Pressure in Oil and Gas Pipes Connectors. Lect. Notes Mech. Eng. 2020, 432-441. [CrossRef]

31. Shatskyi, I.; Ropyak, L.; Velychkovych, A. Model of contact interaction in threaded joint equipped with spring-loaded collet. Eng. Solid Mech. 2020, 8, 301-312. [CrossRef]

32. Striletskyi, Y.Y.; Melnychuk, S.I.; Gryga, V.M.; Pashkevych, O.P. Using broadband signals for structural change detection in metal details. Nauk. Visnyk Natsionalnoho Hirnychoho Universytetu 2020, 3, 19-26. [CrossRef]

33. Saakiyan, L.S.; Efremov, A.P.; Ropyak, L.Y.; Gorbatskii, A.V. A method of microelectrochemical investigations. Sov. Mater. Sci. 1987, 23, 267-269. [CrossRef]

34. Saakiyan, L.S.; Efremov, A.P.; Ropyak, L.Y. Effect of stress on the microelectrochemical heterogeneity of steel. Prot. Met. 1989, 25, 185-189.

35. Chudyk, I.; Poberezhny, L.; Hrysanchuk, A.; Poberezhna, L. Corrosion of drill pipes in high mineralized produced waters. Procedia Struct. Integr. 2019, 16, 260-264. [CrossRef]

36. Shats'kyi, I.P.; Makoviichuk, M.V. Contact interaction of crack lips in shallow shells in bending with tension. Mater. Sci. 2005, 41, 486-494. [CrossRef]

37. Guillal, A.; Abdelbaki, N.; Bensghier, M.E.A.; Betayeb, M.; Kopei, B. Effect of shape factor on structural reliability analysis of a surface cracked pipeline-parametric study. Frat. Integrita Strutt. 2019, 13, 341-349. [CrossRef]

38. Shatskyi, I.P.; Makoviichuk, M.V.; Shcherbii, A.B. Equilibrium of cracked shell with flexible coating. In Proceedings of the 11th International Conference on Shell Structures: Theory and Applications, Gdansk, Poland, 11-13 October 2017; pp. 165-168. [CrossRef]

39. Shats'kyi, I.P.; Makoviichuk, M.V.; Shcherbii, A.B. Influence of a flexible coating on the strength of a shallow cylindrical shell with longitudinal crack. J. Math. Sci. 2019, 238, 165-173. [CrossRef]

40. Shatskyi, I.P.; Perepichka, V.V.; Ropyak, L.Y. On the influence of facing on strength of solids with surface defects. Metallofiz. Noveishie Tekhnologii 2020, 42, 69-76. [CrossRef]

41. Ropyak, L.Y.; Makoviichuk, M.V.; Shatskyi, I.P.; Pritula, I.M.; Gryn, L.O.; Belyakovskyi, V.O. Stressed state of laminated interference-absorption filter under local loading. Funct. Mater. 2020, 27, 638-642. [CrossRef]

42. Mandryk, O.; Artym, V.; Shtohry, M.; Zaytsev, V. Scientific Rationale for the Movable Pipeline Technology for Transporting CNG by Sea. Manag. Syst. Prod. Eng. 2020, 28, 168-177. [CrossRef]

43. Yakym, R.S.; Petryna, D.Y. Analysis of causes and preventing ways of early workability loss of three-cone rock bit cutters. Metallofiz. Noveishie Tekhnologii 2020, 42, 731-751. [CrossRef] 
44. Vytyaz, O.; Chudyk, I.; Mykhailiuk, V. Study of the effects of drilling string eccentricity in the borehole on the quality of its cleaning. New Dev. Min. Eng. 2015, 591-595.

45. Krol, R.; Kawalec, W.; Gladysiewicz, L. An effective belt conveyor for underground ore transportation systems. IOP Conf.Ser. Earth Environ.Sci. 2017, 95, 042047. [CrossRef]

46. Król, R. Studies of the durability of belt conveyor idlers with working loads taken into account. IOP Conf. Ser. Earth Environ. Sci. 2017, 95. [CrossRef]

47. Król, R.; Kisielewski, W. Research of loading carrying idlers used in belt conveyor-practical applications. Diagnostyka 2014, 15, 67-74.

48. Ropyak, L.Y.; Pryhorovska, T.O.; Levchuk, K.H. Analysis of Materials and Modern Technologies for PDC Drill Bit Manufacturing. Prog. Phys. Met. 2020, 21, 274-301. [CrossRef]

49. Nurpeissova, M.; Bekbassarov, S.; Bek, A.; Kyrgizbaeva, G.; Turisbekov, S.; Ormanbekova, A. The geodetic monitoring of the engineering structures stability conditions. J. Eng. Appl. Sci. 2020, 12, 9151-9163. [CrossRef]

50. Onysko, O.; Panchuk, V.; Kopei, V.; Havryliv, Y.; Schuliar, I. Investigation of the influence of the cutter-tool rake angle on the accuracy of the conical helix in the tapered thread machining. J. Phys. Conf. Ser. 2021, 1781, 012028. [CrossRef]

51. Medvid, I.; Onysko, O.; Panchuk, V.; Pituley, L.; Schuliar, I. Kinematics of the Tapered Thread Machining by Lathe: Analytical Study. Lect. Notes Mech. Eng. 2021, 555-565. [CrossRef]

52. Danil'chenko, Y.M. Increasing the accuracy of rotation of high-speed spindle units on anti-friction bearings. Sov. Eng. Res. 1987, 7, 61-63.

53. Muthukumaran, G.; Dinesh Babu, P. Laser transformation hardening of various steel grades using different laser types. J. Braz. Soc. Mech. Sci. Eng. 2021, 43, 1-529. [CrossRef]

54. Ropyak, L.Y.; Vytvytskyi, V.S.; Velychkovych, A.S.; Pryhorovska, T.O.; Shovkoplias, M.V. Study on grinding mode effect on external conical thread quality. IOP Conf. Ser. Mater. Sci. Eng. 2021, 1018, 012014. [CrossRef]

55. Ostapovets, A.; Molnár, P.; Jäger, A. Visco-plastic self-consistent modelling of a grain boundary misorientation distribution after equal-channel angular pressing in an AZ31 magnesium alloy. J. Mater. Sci. 2013, 48, 2123-2134. [CrossRef]

56. Kuanyshbekovna, M.M.; Krupnik, L.; Koptileuovich, Y.K.; Mukhtar, E.; Roza, A. The system is "roof bolting-mountain". Int. J. Appl. Eng. Res. 2016, 11, 10454-10457.

57. Zeynullin, A.A.; Abeuov, E.A.; Demin, V.F.; Aliev, S.B.; Kaynazarova, A.S.; Kaynazarov, A.S. Estimation of ways to maintain mining works based on the application of anchor anchoring in the mines of the Karaganda coal basin. Ugol 2021, 2, 4-9. [CrossRef]

58. Tatarenko, V.A.; Radchenko, T.M.; Nadutov, V.M. Parameters of Interatomic Interaction in a Substitutional Alloy F.C.C. Ni-Fe According to Experimental Data about the Magnetic Characteristics and Equilibrium Values of Intensity of a Diffuse Scattering of Radiations. Metallofiz. Noveishie Tekhnologii 2003, 25, 1303-1319.

59. Radchenko, T.M.; Tatarenko, V.A.; Bokoch, S.M. Diffusivities and kinetics of short-range and long-range orderings in Ni-Fe permalloys. Metallofiz. Noveishie Tekhnologii 2006, 28, 1699-1720.

60. Levchuk, K.H.; Radchenko, T.M.; Tatarenko, V.A. High-Temperature Entropy Effects in Tetragonality of the Ordering InterstitialSubstitutional Solution Based on Body-Centred Tetragonal Metal. Metallofiz. Noveishie Tekhnologii 2021, 43, 1-26. [CrossRef]

61. Tarel'nik, V.B.; Konoplyanchenko, E.V.; Kosenko, P.V.; Martsinkovskii, V.S. Problems and Solutions in Renovation of the Rotors of Screw Compressors by Combined Technologies. Chem. Pet. Eng. 2017, 53, 540-546. [CrossRef]

62. Tarelnik, V.B.; Gaponova, O.P.; Konoplyantschenko, E.V.; Yevtushenko, N.S.; Gerasimenko, V.A. Analysis of the structural state of the surface layer after electro-erosive alloying. II. Peculiarities of the formation of electroerosive coatings on special steels and stops by hard wear-resistant and soft antifriction materials. Metallofiz. Noveishie Tekhnologii 2018, 11, 795-815. [CrossRef]

63. Tarelnyk, V.B.; Gaponova, O.P.; Konoplianchenko, Y.V.; Martsynkovskyy, V.S.; Tarelnyk, N.V.; Vasylenko, O.O. Improvement of quality of the surface electroerosive alloyed layers by the combined coatings and the surface plastic deformation. I. Features of formation of the combined electroerosive coatings on special steels and alloys. Metallofiz. Noveishie Tekhnologii 2019, 41, 47-69. [CrossRef]

64. Ivanov, O.; Prysyazhnyuk, P.; Lutsak, D.; Matviienkiv, O.; Aulin, V. Improvement of Abrasion Resistance of Production Equipment Wear Parts by Hardfacing with Flux-Cored Wires Containing Boron Carbide/Metal Powder Reaction Mixtures. Manag. Syst. Prod. Eng. 2020, 28, 178-183. [CrossRef]

65. Cizek, J.; Dlouhy, I.; Siska, F.; Khor, K.A. Modification of Plasma-sprayed TiO2 Coatings Characteristics via Controlling the In-flight Temperature and Velocity of the Powder Particles. J. Therm. Spray Technol. 2014, 23, 1339-1349. [CrossRef]

66. Duryahina, Z.A.; Kovbasyuk, T.M.; Bespalov, S.A.; Pidkova, V.Y. Micromechanical and Electrophysical Properties of Al2O3 Nanostructured Dielectric Coatings on Plane Heating Elements. Mater. Sci. 2016, 52, 50-55. [CrossRef]

67. Matei, A.A.; Pencea, I.; Stanciu, S.G.; Hristu, R.; Antoniac, I.; Ciovica, E.; Sfat, C.E.; Stanciu, G.A. Structural characterization and adhesion appraisal of TiN and TiCN coatings deposited by CAE-PVD technique on a new carbide composite cutting tool. J. Adhes. Sci. Technol. 2015, 29, 2576-2589. [CrossRef]

68. Prysyazhnyuk, P.; Lutsak, D.; Shlapak, L.; Aulin, V.; Lutsak, L.; Borushchak, L.; Shihab, T.A. Development of the composite material and coatings based on niobium carbide. East. Eur. J. Enterp. Technol. 2018, 6, 43-49. [CrossRef]

69. Duryagina, Z.A.; Bespalov, S.A.; Pidkova, V.Y.; Polockyj, D.Y. Examination of the dielectric layers on the structural materials formed by hybrid ion-plasma discharge system. Metallofiz. Noveishie Tekhnologii 2011, 33, 393-400. 
70. Pashechko, M.; Montusiewicz, J.; Dziedzic, K.; Jozwik, J. Multicriterion Assessment of Wear Resistance of Fe-Mn-C-B Eutectic Coatings Alloyed with Si, Ni, and Cr. Powder Metall. Met. Ceram. 2017, 56, 316-322. [CrossRef]

71. Pashechko, M.I.; Dziedzic, K.; Mendyk, E.; Jozwik, J. Chemical and Phase Composition of the Friction Surfaces Fe-Mn-C-B-Si-NiCr Hardfacing Coatings. J. Tribol. 2018, 140, 021302. [CrossRef]

72. Chudyk, I.; Raiter, P.; Grydzhuk, Y.; Yurych, L. Mathematical model of oscillations of a drill tool with a drill bit of cutting-scraping type. Nauk. Visnyk Natsionalnoho Hirnychoho Universytetu 2020, 1, 52-57. [CrossRef]

73. Pryhorovska, T. Rock heterogeneity numerical simulation as a factor of drill bit instability. Eng. Solid Mech. 2018, 6, 315-330. [CrossRef]

74. Pryhorovska, T.O. Study on rock reaction force depending on PDC cutter placement. Mach. Sci. Technol. 2017, 21, 37-66. [CrossRef]

75. Pryhorovska, T.A.; Chaplinskiy, S.S. Finite element modeling of rock mass cutting by cutters for PDC drill bits. Neftyanoe Khozyaystvo-Oil Ind. 2018, 1, 38-41. [CrossRef]

76. Pryhorovska, T.O.; Chaplinskyy, S.S. Probabilistic estimate of pdc drill bit wear rate. Naukovyi Visnyk Natsionalnoho Hirnychoho Universytetu 2014, 5, 39-45.

77. Tatsii, R.M.; Pazen, O.Y. Direct (Classical) Method of Calculation of the Temperature Field in a Hollow Multilayer Cylinder. J. Eng. Phys. Thermophys. 2018, 91, 1373-1384. [CrossRef]

78. Tatsiy, R.M.; Pazen, O.Y.; Vovk, S.Y.; Ropyak, L.Y.; Pryhorovska, T.O. Numerical study on heat transfer in multilayered structures of main geometric forms made of different materials. J. Serb. Soc. Comput. Mech. 2019, 13, 36-55. [CrossRef]

79. Tatsiy, R.M.; Pazen, O.Y.; Vovk, S.Y.; Kharyshyn, D.V. Direct method of studying heat exchange in multilayered bodies of basic geometric forms with imperfect heat contact. Naukovyi Visnyk Natsionalnoho Hirnychoho Universytetu 2021, 60-67. [CrossRef]

80. Kopei, V.B.; Onysko, O.R.; Panchuk, V.G. Principles of development of product lifecycle management system for threaded connections based on the Python programming language. J. Phys. Conf. Ser. 2020, 1426, 012033. [CrossRef]

81. Levchuk, K.G.; Moisyshyn, V.M.; Tsidylo, I.V. Influence of mechanical properties of a material on dynamics of the stuck drilling pipes. Metallofiz. Noveishie Tekhnologii 2016, 38, 1655-1668. [CrossRef]

82. Petlovanyi, M.; Lozynskyi, V.; Saik, P.; Sai, K. Predicting the producing well stability in the place of its curving at the underground coal seams gasification. E3S Web Conf. 2019, 123, 01019. [CrossRef]

83. Velichkovich, A.; Dalyak, T.; Petryk, I. Slotted shell resilient elements for drilling shock absorbers. Oil Gas Sci. Technol. Rev. IFP Energ. Nouv. 2018, 73, 34. [CrossRef]

84. Moisyshyn, V.M.; Lyskanych, M.V.; Borysevych, L.V.; Kolych, N.B.; Zhovniruk, R.A. Integral Indicators of Change of Drilling Column Vibration-Criterion for Assessing of Roller Cone Bit Wear. Metallofiz. Noveishie Tekhnologii 2019, 41, 1087-1102. [CrossRef]

85. Mikhlin, Y.V.; Zhupiev, A.L. An application of the ince algebraization to the stability of non-linear normal vibration modes. Int. J. Non-Linear Mech. 1997, 32, 393-409. [CrossRef]

86. Grydzhuk, J.; Chudyk, I.; Velychkovych, A.; Andrusyak, A. Analytical estimation of inertial properties of the curved rotating section in a drill string. East. Eur. J. Enterp. Technol. 2019, 1, 6-14. [CrossRef]

87. Dutkiewicz, M.; Gołębiowska, I.; Shatskyi, I.; Shopa, V.; Velychkovych, A. Some aspects of design and application of inertial dampers. MATEC Web of Conf. 2018, 178, 06010. [CrossRef]

88. Shatskyi, I.; Velychkovych, A. Increase of compliance of shock absorbers with cut shells. IOP Conf.Ser. Mater. Sci. Eng. 2019, 564, 012072. [CrossRef]

89. Velychkovych, A.; Petryk, I.; Ropyak, L. Analytical study of operational properties of a plate shock absorber of a sucker-rod string. Shock Vib. 2020, 3292713. [CrossRef]

90. Shatskyi, I.; Popadyuk, I.; Velychkovych, A. Hysteretic Properties of Shell Dampers. Springer Proc. Math. Stat. 2018, 249, 343-350. [CrossRef]

91. Bulbuk, O.; Velychkovych, A.; Mazurenko, V.; Ropyak, L.; Pryhorovska, T. Analytical estimation of tooth strength, restored by direct or indirect restorations. Eng. Solid Mech. 2019, 7, 193-204. [CrossRef]

92. Velichkovich, A.S.; Dalyak, T.M. Assessment of stressed state and performance characteristics of jacketed spring with a cut for drill shock absorber. Chem. Pet. Eng. 2015, 51, 188-193. [CrossRef]

93. Levchuk, K.G. Investigation of the vibration transfer process to a stuck drill string. SOCAR Proc. 2017, 2, 23-33. [CrossRef]

94. Moisyshyn, V.; Levchuk, K. Investigation on Releasing of a Stuck Drill String by Means of a Mechanical Jar. Oil Gas Sci. Technol. 2017, 72, 27-35. [CrossRef]

95. Levchuk, K.G. Diagnosis of catches of metal drill pipes by their stress-strain state in a sloping well. Metallofiz. Noveishie Tekhnologii 2018, 40, 701-712. [CrossRef]

96. Shatskyi, I.; Perepichka, V. Problem of Dynamics of an Elastic Rod with Decreasing Function of Elastic-Plastic External Resistance. Springer Proc. Math. Stat. 2018, 249, 335-342. [CrossRef]

97. Shatskyi, I.; Vytvytskyi, I.; Senyushkovych, M.; Velychkovych, A. Modelling and improvement of the design of hinged centralizer for casing. IOP Conf. Ser. Mater. Sci. Eng. 2019, 564, 12073. [CrossRef]

98. Velychkovych, A.S.; Andrusyak, A.V.; Pryhorovska, T.O.; Ropyak, L.Y. Analytical model of oil pipeline overground transitions, laid in mountain areas. Oil Gas Sci. Technol. 2019, 74, 65. [CrossRef]

99. Tyrlych, V.; Moisyshyn, V. Predicting remaining lifetime of drill pipes basing upon the fatigue crack kinetics within a pre-critical period. Min. Miner. Depos. 2019, 13, 127-133. [CrossRef] 
100. Vytvytskyi, I.I.; Seniushkovych, M.V.; Shatskyi, I.P. Calculation of distance between elastic-rigid centralizers of casing. Nauk. Visnyk Natsionalnoho Hirnychoho Universytetu 2017, 5, 28-35.

101. Shatskyi, I.; Velychkovych, A.; Vytvytskyi, I.; Seniushkovych, M. Analytical models of contact interaction of casing centralizers with well wall. Eng. Solid Mech. 2019, 7,355-366. [CrossRef]

102. Jiang, K.; Xie, R.; Yun, H. Lightweight drill pipe based on composite carbon fiber material. J. Phys. Conf. Ser. 2020, 1549, 032113. [CrossRef]

103. Benyahia, H.; Tarfaoui, M.; El Moumen, A.; Ouinas, D. Prediction of notched strength for cylindrical composites pipes under tensile loading conditions. Compos. Part B Eng. 2018, 150, 104-114. [CrossRef]

104. Fyk, M.; Biletskyi, V.; Abbood, M.; Al-Sultan, M.; Abbood, M.; Abdullatif, H.; Shapchenko, Y. Modeling of the lifting of a heat transfer agent in a geothermal well of a gas condensate deposit. Min. Miner. Depos. 2020, 14, 66-74. [CrossRef]

105. Kolosov, D.; Snihur, V.; Pysmenkova, T. Stress-strain state of rubber-cable tractive element of tubular shape. Rozrob. Rodov. 2020, $14,43-52$.

106. Galiyev, D.A.; Uteshov, E.T.; Tekenova, A.T. Digitalization of technological and organizational processes of mining operations due to the implementation of the installation system and accounting the key indicators. News Natl. Acad. Sci. Repub. Kazakhstan Ser. Geol. Tech. Sci. 2020, 5, 47-53. [CrossRef]

107. Yu, B.; Zhang, J.J.; Zhao, J.P.; Ma, T.J. Mechanical Study of Carbon Fiber Reinforced Plastic and Thin-walled Metal Liner in Bi-Material COPV Based on Grid Theory Optimization. Mater. Sci. Forum 2021, 1027, 15-21. [CrossRef] 